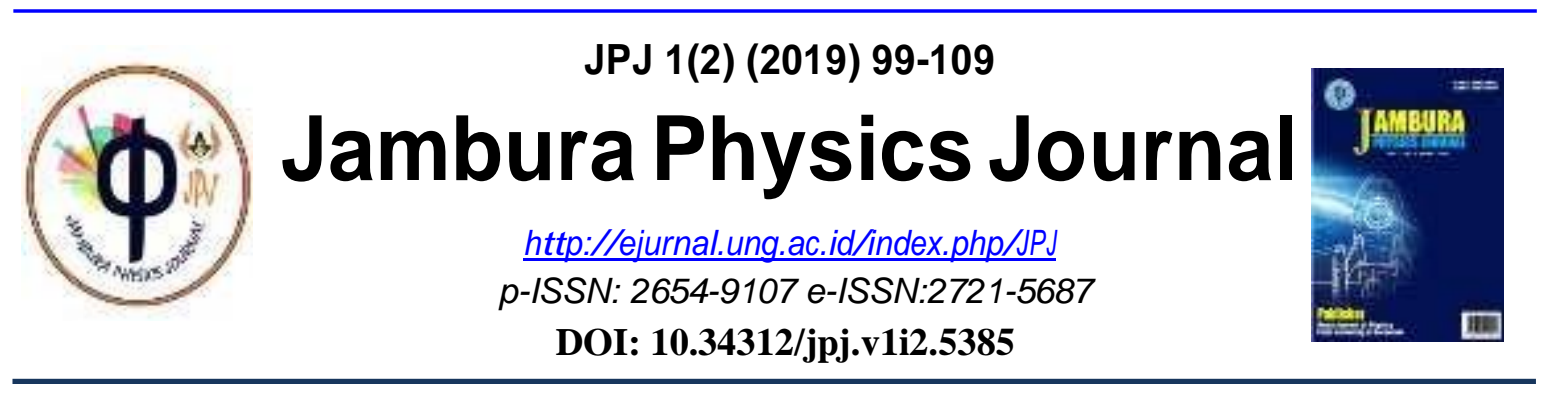

\title{
UJI KONDUKTIVITAS FILM ELEKTROLIT POLIMER KITOSAN CANGKANG KEPITING DENGAN PENAMBAHAN KCI
}

\author{
Safitri F. ${ }^{1}$, Supu I.*2 \\ ${ }^{1}$ Universitas Cokroaminoto Palopo, Palopo \\ ${ }^{2}$ Jurusan Fisika Universitas Negeri Gorontalo, Gorontalo
}

Accepted: August 27 2019. Approved: October 07 2019. Published: October 302019

\begin{abstract}
Abstrak
Penelitian ini bertujuan untuk mengetahui gugus fungsi kitosan sebelum dan setelah penambahan $\mathrm{KCl}$ dan mengetahui uji konduktivitas film elektrolit polimer kitosan cangkang kepiting dengan penambahan $\mathrm{KCl}$. Hasil pengujian nilai gugus fungsi $\mathrm{N}-\mathrm{H}$ pada bilangan gelombang $3444.87 \mathrm{~cm}^{-1}$. Sedangkan gugus fungsi C-O terdapat pada bilangan gelombang $1024.20 \mathrm{~cm}^{-1}$. Gugus fungsi C-H (alkana) dengan terdapat pada panjang gelombang $2854 \mathrm{~cm}^{-1}$ sedangkan pada gugus fungsi $-\mathrm{C}=\mathrm{C}$ aromatis terdapat pada bilangan gelombang $1450 \mathrm{~cm}^{-1}$. Gugus fungsi $\mathrm{CH}_{3}$ didapat pada bilangan gelombang $1281 \mathrm{~cm}^{-1}$ dan $1340 \mathrm{~cm}^{-1}$, gugus fungsi C-O didapat pada bilangan 1100, sedangkan gugus fungsi $\mathrm{C}=\mathrm{H}$ (tekuk luar bidang) terdapat pada bilangan $949 \mathrm{~cm}^{-1}$, dan gugus fungsi $\mathrm{C}-\mathrm{X}$ terdapat pada bilangan $840 \mathrm{~cm}^{-1}$. PEG dan $\mathrm{KCl} 25 \%$ sebesar $12.615 \mathrm{~S} / \mathrm{cm}$. sedangkan konduktivitas pada kitosan dengan penambahan 35\% sebesar $180.440 \mathrm{~S} / \mathrm{cm}$, sedangkan nilai konduktivitas kitosan $45 \%$ sebesar $326.319 \mathrm{~S} / \mathrm{cm}$. penambahan $\mathrm{KCl}$ pada kitosan terbukti meningkat apabila konsentrasinya terus bertambah.
\end{abstract}

Kata kunci: Kitosan, $\mathrm{KCl}$, PEG

\section{PENDAHULUAN}

Kepiting bakau (Scylla spp.) hidup pada perairan pantai terutama pantai yang ditumbuhi mangrove, perairan dangkal sekitar ekosistem mangrove, estuari dan pantai berlumpur. Kepiting bakau memiliki peranan ekologis dalam ekosistem mangrove dan merupakan salah satu komoditi perikanan yang bernilai ekonomis penting. Sebagai makanan asal laut. Kepiting merupakan komoditas ekspor unggulan Indonesia berasal dari produksi perairan.

*Alamat Korespondensi

E-mail: idawatisupu20@gmail.com 
Dari data Kementrian Kelautan dan Perikanan pada Januari-Agustus 2011, nilai ekspor kepiting mencapai US\$ 172 juta. Peningkatan terus terjadi dari tahun-ke tahun, terlihat dari data pada sepanjang tahun 2010 ekspor kepiting hanya mencapai US\$ 208 juta. Keuntungan dari hasil perairan berupa kepiting tersebut memunculkan masalah yaitu semakin banyak limbah cangkang kepiting yang dihasilkan, menumpuk dari tahun ke tahun. (Nurul dkk, 2014).

Kitosan merupakan biopolimer berasal dari pengolahan Kitin kandungan cangkang luar Crustaceae, serangga, dan beberapa jenis jamur. Kitosan mempunyai berbagai sifat, salah satunya sebagai absorben, atau pengikat ion. Kepiting (Brachyura) merupakan salah satu jenis Crustaceae sebagai sumber Kitin. Kitosan merupakan biopolimer, bersifat tidak racun, biodegradabel dan memiliki gugus pasangan elektron bebas yang dapat dijadikan elektrolit polimer dengan nilai konduktivitas ion yang baik (Kadapi, 2013).

Beberapa tahun terakhir, telah dilakukan penelitian untuk menggunakan bahan polimer alam (biopolimer) dari kitosan karena lebih ekonomis karena ketersediaanya yang melimpah, sifat fleksibilitas yang tinggi, tidak beracun dan memiliki sifat koduktivitas yang baik (Yuan, et al.2009; Fonseca, and Neves 2006). Dengan sifat koduktivitas tersebut sehingga dapat diaplikasikan dalam berbagai perangkat elektronik dan pembuatan sensor (Yahya dan Arof, 2004). Elektrolit polimer kitosan dapat berbentuk cair maupun padat. Elektrolit kitosan cair memiliki kekurangan seperti stabilitas yang rendah karena mudah terjadi kebocoran. Beberapa penelitian telah mengembangkan elektrolit kitosan padat (Yahya and Arof 2003; Kadir et al. 2011; Shujahadeen et.al. 2010; Diana, 2018).

Pembuatan elektrolit polimer dilakukan untuk menghomogenkan campuran kitosan dengan bahan lain sehingga terbentuk film elektrolit yang akan mudah diukur nilai konduktivitasnya. Pengukuran konduktivitas listik dilakukan untuk menilai kontribusi berbagai kelompok ion yang terdapat dalam bahan elektrolit polimer. Kitosan juga berperan sebagai polimer media untuk elektrolit karena kitosan dapat melarutkan garam-garam ionik untuk meningkatkan konduktivitas ioniknya. Selain itu, pergerakan ion tersebut dapat ditingkatkan dengan menambahkan bahan plasticizer (Oesman, et.al. 2001). Kitosan juga dapat dimodifikasi dengan cara dicampur dengan polimer lain seperti poliethylene glycol (PEG). Beberapa penelitian menyatakan bahwa penambahan PEG dapat memperbaiki elastisitas dari kitosan. Penambahan $\mathrm{KCl}$ berperan dalam meningkatkan konduktivitas (Kadapi, 2013). Oleh karena itu $\mathrm{KCl}$ sangat berpotensi untuk dijadikan campuran dalam pembuatan film elektrolit polimer kitosan, sehingga campuran kitosan, PEG dan $\mathrm{KCl}$ dapat dimanfaatkan untuk berbagai macam aplikasi perangkat elektronik. 
Penelitian mengenai elektrolit polimer kitosan masih terus perlu dilakukan. Salah satu senyawa alami yang berpotensi untuk digunakan sebagai bahan ekektrolit polimer adalah kitosan yang berasal dari limbah cangkang kepiting. Pembuatan polimer kitosan dengan menggunakan limbah cangkang kepiting memiliki prospek yang sangat baik untuk dimanfaatkan dalam teknologi material. Sehingga penulis bermaksud melakukan penelitian mengenai uji konduktivitas larutan elektrolit polimer kitosan pada cangkang kepiting dengan penambahan $\mathrm{KCl}$.

Adapun tujuan dari penelitian ini yaitu:

1. Mengetahui gugus fungsi pada kitosan sebelum penambahan $\mathrm{KCl}$

2. Mengetahui gugus fungsi kitosan cangkang kepiting setelah penambahan $\mathrm{KCl}$

3. Mengetahui uji konduktivitas film elektrolit polimer kitosan cangkang kepiting dengan penambahan $\mathrm{KCl}$.

\section{METODE PENELITIAN}

Jenis penelitian yang digunakan dalam penelitian ini adalah eksperimen yaitu untuk mengetahui konduktivitas larutan elektrolit polimer kitosan pada cangkang kepiting dengan penambahan $\mathrm{KCl}$.

Alat yang digunakan dalam penelitian ini adalah seperangkat alat gelas, mixer, neraca analitik, oven, kertas saring, mortar, blender, corong, batang pengaduk, $\mathrm{pH}$ meter universal, termometer, serta LCR meter Hitester 3522-50.

Bahan-bahan yang digunakan yaitu cangkang kepiting, Asam Klorida, Natrium Hidroksida, aquadest, asam asetat, akuabides, PolyethylenGlikol, $\mathrm{KCl}$.

\section{Prosedur kerja}

a. Isolasi kitin dari cangkang kepiting

Transformasi kitin menjadi kitosan itu ada tiga tahap yaitu:

1) Tahap Deproteinasi

Pada tahap ini massa kepiting ditimbang sebanyak 50 gram lalu ditambahkan larutan $\mathrm{NaOH} 1$ Molar sebanyak 16 gram diencerkan dengan akuades $484 \mathrm{ml}$. dengan perbandingan 1:10 diaduk pada suhu $60-70{ }^{\circ} \mathrm{C}$ selama 2 jam pH pada tahap ini adalah 13 , kemudian disaring untuk diambil endapannya, endapan dicuci dengan aquades sampai netral dan dikeringkan pada suhu $60{ }^{\circ} \mathrm{C}$ selama 1 jam. Massa sampel yang tersisa pada tahap ini yaitu 70 gram. Deproteinasi bertujuan untuk memisahkan protein yang terdapat pada cangkang kepiting bakau dilakukan dengan menggunakan larutan natrium hidroksida. 
2) Tahap demineralisasi

Sebanyak 70 gram bubuk kitin dilarutkan dengan $\mathrm{HCl} 700 \mathrm{ml}$ konsentasi $2 \mathrm{M}$, dengan perbandingan 1:10. Diaduk selama 3 jam pada suhu ruang. kemudian disaring untuk diambil endapannya, lalu endapan dicuci dengan aquades sampai ph netral dan dikeringkan dengan suhu $60{ }^{\circ} \mathrm{C}$ selama 1 jam. Massa sampel yang tersisa pada tahap ini yaitu 6.6 gram. Demineralisasi dilakukan dengan menggunakan larutan asam klorida dan reaksi yang terjadi antara mineral dengan asam klorida mengikuti reaksi.

3) Tahap deasetilasi

Sebanyak 6.6 gram massa kitin yang diperoleh melalui proses demineralisasi ditambahkan dengan natrium hidroksida 50\% dengan perbandingan 1:10 di panaskan pada temperature $90-100{ }^{\circ} \mathrm{C}$ selama 30 menit sambil diaduk dengan pengaduk magnetik. Setelah dingin, padatan disaring dan residu yang tertinggal dicuci dengan air bebas mineral hingga $\mathrm{pH}$ netral dalam kisaran 6-7. Padatan yang diperoleh berupa kitosan dan dikeringkan dalam oven dengan suhu $60{ }^{\circ} \mathrm{C}$ selama 4 jam. Kitin yang diperoleh kemudian dideasetilasi untuk mendapatkan kitosan. Pada proses ini terjadi pemutusan gugus asetil dengan atom nitrogen yang terdapat pada kitin sehingga menghasilkan suatu amina yang merupakan gugus yang terdapat pada kitosan.

4) Pembuatan Film Kitosan+PEG $+\mathrm{KCl}$

Sebanyak 0.5 gram kitosan masing -masing dicampur dengan 0.3 gram PEG. selanjutnya campuran kitosan dan PEG dilarutkan dalam $10 \mathrm{ml}$ asam asetat 1\%, proses pencampuran dilakukan dengan menggunakan hot plate stirrer pada putaran $360 \mathrm{rpm}$ dengan suhu $60^{\circ} \mathrm{C}$ selama 90 menit sampai campuran homogen. Setelah campuran homogen, suhu diturunkan menjadi suhu ruang, campuran kitosan, PEG yang telah homogen ditambahkan $\mathrm{KCl}$ dengan variasi konsentrasi $25 \% \mathrm{wt}, 35 \% \mathrm{wt}, 45 \% \mathrm{wt}$, proses pencampuran dilakukan selama \pm 6 jam. Setelah itu dicetak dengan wadah kaca kemudian dilakukan dokumentasi visual berupa bentuk dan ketebalan dari film elektrolit polimer kitosan.

5) Pengujian

Nilai Konduktivitas listrik diukur dengan menggunakan LCR Meter Hitester 3522-50. Besarnya nilai konduktivitas listrik diperoleh dengan mencari nilai konduktansinya. Tahap pengukuran meliputi film elektrolit polimer dipotong dengan ukuran $2 \times 1 \mathrm{~cm}$, kemudian dijepit pada plat pengukur konduktivitas sebagai elektrodanya, frekuensi yang digunakan adalah $1 \mathrm{KHz}$. 


\section{Teknik analisis data}

Hasil pengukuran konduktivitas listrik menggunakan LCR Meter Hitester kemudian dihitung dengan persamaan (1) Nilai konduktivitas yang diperoleh dengan menggunakan rumus diatas kemudian di plot pada grafik sehingga akan muncul grafik nilai konduktivitas pada tiap sampel.

\section{HASIL DAN PEMBAHASAN}

\section{Hasil Penelitian}

\section{Isolasi Kitin Menjadi Kitosan}

Berdasarkan penelitian yang telah dilakukan, proses isolasi kitosan dilakukan dengan tiga tahap yaitu tahap deproteinasi menggunakan $\mathrm{NaOH} 1 \mathrm{M}$ dengan perbandingan 1:10 (gr serbuk: $\mathrm{ml} \mathrm{NaOH}$ ). Dari tahap ini sebanyak 50 gr serbuk cangkang kepiting yang dilarutkan dengan $\mathrm{NaOH}$ menghasilkan 70 gr massa kitin. Pada tahap selanjutnya sebanyak 70 gr kitin yang dihasilkan di tambahkan dengan HCL konsentrasi 2M dengan perbandingan 1:10 (gr serbuk: ml HCL). Sehingga menghasilkan senyawa kitin sebanyak 6,6 gr. Pada tahap akhir yaitu tahap deasetilasi bubuk kitin sebanyak 6,6 gr dilarutkan dengan $\mathrm{NaOH}$ konsentrasi $50 \%$ dengan perbandingan 1:10 (gr serbuk : $\mathrm{ml} \mathrm{NaOH}$ ). Pada tahap ini berfungsi untuk menghilangkan gugus asetil yang terkandung dalam kitin sehingga diperoleh senyawa kitosan. Pada tahap akhir ini senyawa kitosan yang dihasilkan sebanyak 3,6 gr kitosan.

\section{Pembuatan film elektrolit polimer kitosan}

Senyawa kitosan yang diperoleh dari proses isolasi kitosan dilanjutkan dengan prosen pembuatan film elektrolit polimer kitosan dengan variasi konsentrasi larutan $\mathrm{KCl}$ sebanyak $25 \%, 35 \%$, dan $45 \%$. Kitosan sebanyak 0,3 gram dan sebanyak 0,2 polietilen glikol dilarutkan dalam $10 \mathrm{ml}$ asam asetat konsentrasi 1\% diaduk hingga homogeny. Setelah itu ditambahkan garam kalium klorida dengan variasai konsentrasi 25\%, 35\% dan 45\%. Polietilen glikol berfungsi sebagai stabilizer sedangkan $\mathrm{KCl}$ berperan untuk meningkatkan konduktivitas kitosan, pada pembuatan film ini menghasilkan 3 sampel polimer kitosan (Kadafi, 2013).

Tabel 1. Kombinasi bahan yang digunakan dalam pembuatan film elektrolit polimer.

\begin{tabular}{ccccc}
\hline Kode sampel & Kitosan $(\mathrm{g})$ & PEG $(\mathrm{g})$ & $\begin{array}{c}\text { Asam asetat } \\
1 \%(\mathrm{ml})\end{array}$ & Garam KCl $(\mathrm{g})$ \\
\hline $25 \%$ & 0.3 & 0.2 & 10 & 0.025 \\
$35 \%$ & 0.3 & 0.2 & 10 & 0.035 \\
$45 \%$ & 0.3 & 0.2 & 10 & 0.045 \\
\hline
\end{tabular}

Sumber: Data primer setelah diolah (2017)

Sebanyak 0.3 gram kitosan dicampur dengan 0.2 gram PEG. Campuran kitosan/PEG dilarutkan dalam $10 \mathrm{ml}$ asam asetat $1 \%$, proses pencampuran dilakukan dengan menggunakan hot plate stirrer pada putaran $350 \mathrm{rpm}$ dengan suhu $60^{\circ} \mathrm{C}$ sampai campuran homogen. Setelah 
campuran homogen, suhu diturunkan menjadi suhu ruang, campuran kitosan/PEG yang telah homogen ditambahkan $\mathrm{KCl}$ dengan variasi konsentrasi $25 \% \mathrm{wt}, 35 \% \mathrm{wt}$, dan $45 \% \mathrm{wt}$, proses pencampuran dilakukan sampai homogen. Campuran kitosan/PEG+KCl yang telah homogen didinginkan pada suhu ruang sehingga mengering dan membentuk film elektrolit polimer Film (Kadafi, 2013).

\section{Uji kadar air}

Analisis kadar air bertujuan untuk mengetahui perbedaan jumlah kadar air yang dihasilkan kitin sebelum menjadi kitosan, kitosan mudah dipahami mengingat proses transformasi kitin menjadi kitosan menggunakan natrium hidroksida merupakan senyawa hidroskopis sehingga kadar air kitosan lebih kecil dibanding dengan kitin. Hasil akhir uji kadar air kitosan sebesar 0.454\%. Adapun standar kadar air kitosan menurut SNI (2006) umumnya yaitu $\leq 10 \%$.

\section{Uji FTIR kitosan}

Analisis FTIR kitosan bertujuan untuk mengetahui gugus fungsi yang terdapat dalam suatu senyawa. Berdasarkan hasil pengujian sampel gugus fungsi pada kitosan murni terdapat gugus fungsi NH DAN C-O. kemunculan banyak puncak ini menunjukkan bahwa didalam sampel kitosan murni terdapat banyak jenis gugus fungsi. Tapi yang ingin diketahui disini apakah yang terbentuk ini kitosan atau hanya kitin saja.

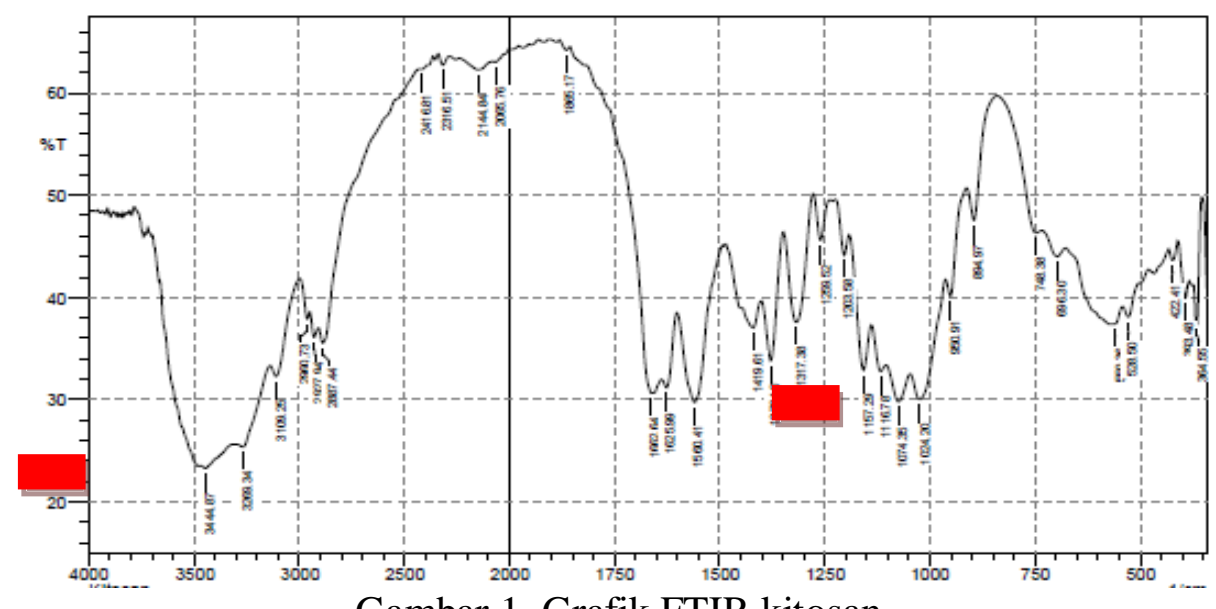

Gambar 1. Grafik FTIR kitosan

\section{Uji FT-IR kitosan+PEG+KCl}

Analisis FTIR kitosan+PEG+KCl bertujuan untuk meneliti struktur suatu elektroit polimer, untuk melihat adanya kompleks garam polimer dalam elektrolit polimer dan mengetahui interaksi antara berbagai unsure dalam elektrolit polimer, interaksi ini dapat menyebabkan perubahan dalam moda vibrasi dari molekul pada elektrolit polimer. Berdasarkan hasil pengujian sampel gugus fungsi pada kitosan+PEG+KCl terdapat gugus 
fungsi $\mathrm{CH},-\mathrm{C}=\mathrm{C}, \mathrm{CH}_{3}, \mathrm{C}=\mathrm{H}, \mathrm{C}-\mathrm{X}$. kemunculan banyak puncak ini menunjukkan bahwa didalam sampel kitosan+PEG+KCl terdapat banyak jenis gugus fungsi. Berikut hasil analisis gugus fungsi sampel kitosan.

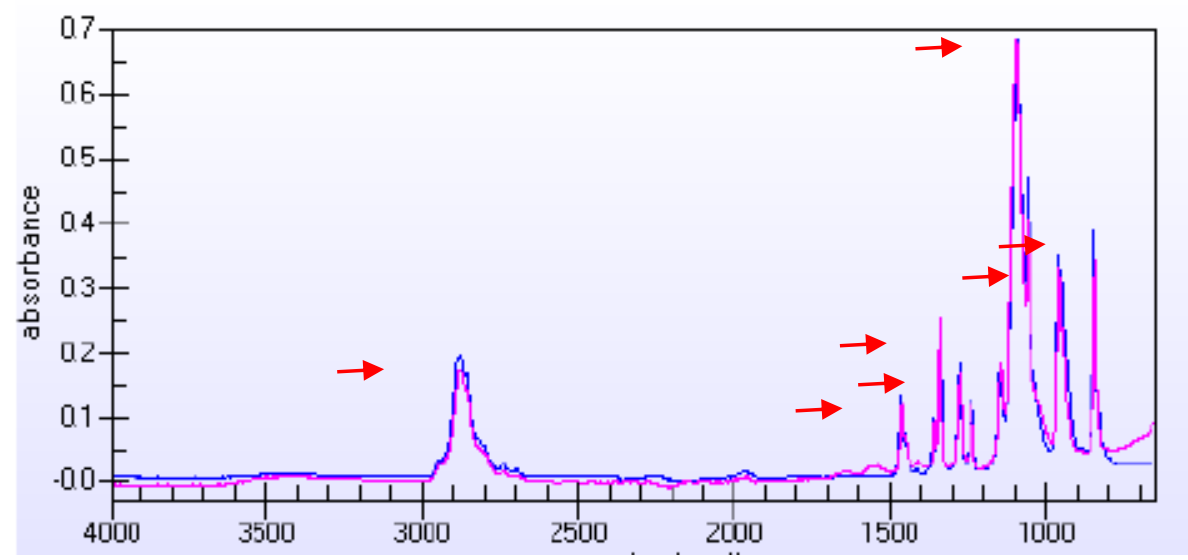

Gambar 2. Grafik FTIR kitosan+PEG+KCl

\section{Uji konduktivitas film elektrolit polimer kitosan pada frekuensi $1000 \mathrm{~Hz}$}

Hasil uji konduktivitas film elektrolit polimer kitosan penambahan $\mathrm{KCl}$ frekuensi 1000 $\mathrm{Hz}$ dapat dilihat pada tabel 2.

Tabel 2. Hasil pengujian film elektrolit polimer kitosan pada frekuensi $1000 \mathrm{~Hz}$

\begin{tabular}{cccccc}
\hline & & & & & Lebar \\
No. & Konsentrasi sampel & Konduktansi $(\mathrm{G})$ & $\begin{array}{c}\text { Panjan } \\
\text { film } \\
(\mathrm{L})\end{array}$ & $\begin{array}{c}\text { film } \\
(\mathrm{A})\end{array}$ & Konduktivitas \\
\cline { 3 - 6 } & $25 \%$ & $\mathrm{~cm}$ & $\mathrm{~cm}$ & $\mathrm{~S} / \mathrm{cm}$ \\
\hline 1. & $35 \%$ & 12.615 & 0.2 & 0.02 & 12.615 \\
2. & $45 \%$ & 18.044 & 0.2 & 0.02 & 180.440 \\
3. & & 32.631 & 0.2 & 0.02 & 326.319 \\
\hline
\end{tabular}

Nilai konduktivitas yang dihasilkan pada polimer kitosan meningkat apabila bertambahnya konsentrasi $\mathrm{KCl}$ pada polimer kitosan. Tapi apabila garam ioniknya melebihi massa kitosan maka film yang akan dihasilkan tidak dapat digunakan karena apabila kandungan garamnya terlalu banyak maka film elektrolit polimer tidak dapat dipindahkan dari kaca preparat melainkan film yang dihasilkan tidak terbentuk dan mudah retak.

\section{Pembahasan}

\section{Proses Isolasi Kitin Menjadi Kitosan}

Hasil dari proses deproteinasi yang telah diperoleh selanjutnya disaring lalu dicuci dengan akuades/akuabides sampai netral. lalu dikeringkan dengan menggunakan oven dengan suhu $60^{\circ} \mathrm{C}$ selama 1 jam untuk mengurangi kandungan ainya kemudian ditimbang untuk mengetahui massa sampel yang tersisa. Massa sampel yang tersisa pada tahap ini yaitu 70 gr. 
Selanjutnya pada tahap demineralisasi dilakukan dengan menggunakan larutan asam lemah $\mathrm{HCl}$ yang bertujuan untuk menghilangkan mineral yang terkandung dalam cangkang kepiting (Elin dkk, 2013).

Hasil demineralisasi selanjutnya disaring dan dicuci dengan akuades/akuabides sampai pada ph netral. untuk menghilangkan kandungan asam yang terdapat pada senyawa kitin. Kemudian sampel dikeringkan dengan menggunakan oven selama 1 jam dan ditimbang untuk mengetahui berat kitin yang terbentuk. Massa kitin yang dihasilkan pada tahap ini yaitu 6.6 gr. Penggunaan konsentrasi $\mathrm{HCl}$ dan suhu reaksi harus diperhatikan karena kitin dapat mencair apabila menggunakan asam dengan konsentrasi terlalu tinggi dan pada temperature yang tinggi $\mathrm{HCl}$ dapat mengakibatkan senyawa kitin terdegradasi (Permana, 2015).

Hasil dari tahap deasetilasi kemudian disaring lalu dicuci dengan akuades/akuabides sampai ph netral. kemudian dikeringkan dengan suhu $60^{\circ} \mathrm{C}$ sampai benar-benar kering. Massa yang dihasilkan pada tahap ini yaitu 3.6 gr.

\section{Proses Pembuatan Film Elektrolit}

Pembuatan film dilakukan menggunakan kitosan dengan campuran PEG, dimana PEG bermanfaat untuk memberi pengaruh suhu pada film elektrolit. PEG juga mudah larut bila dicampurkan dengan kitosan, setelah itu campuran film di tambahkan dengan $\mathrm{KCl}$ konsentrasi 25\%, 35\%, dan 45\%. Tampilan yang dihasilkan film elektrolit yaitu berwarna bening dan mengental hal ini disebabkan karena campuran PEG dan $\mathrm{KCl}$ tercampur homogen.

\section{Analisis Kadar Air}

Hasi dari analisis Kadar air kitin menjadi kitosan menunjukka bahwa kadar air kitin lebih tinggi dibanding kitosan. Dimana ekstraksi yang dihasilkan kitin sebesar 6.6 gr, sedangkan ekstraksi yang dihasilkan kitosan sebesar 3.6 gr. Dihitung dengan menggunakan rumus hasil dari analisis kadar air menunjukkan $0.454 \%$. Kitin mempunyai kekuatan mengikat molekul-molekul air lebih tinggi dibandingkan kitosan. Banyaknya molekul air yang terikat pada kitin dibandingkan kitosan kemungkinan disebabkan oleh protein yang melingkupi rantai kitin karena gugus peptina pada rantai protein potensial mengikat pada molekul air. (SNI, 2006)

\section{Gugus Fungsi yang Terkandung pada Kitosan}

Spektrum FTIR menunjukkan adanya gugus fungsi N-H pada bilangan gelombang $344487 \mathrm{~cm}^{-1}$. Gugus fungsi C-O terdeteksi pada bilangan gelombang $1024.20 \mathrm{~cm}^{-1}$. Hasil FTIR kitosan murni yang dihasilkan pada penelitian ini tidak jauh berbeda dengan penelitian sebelumnya yang dilakukan oleh (Putri, 2009). 


\section{Gugus Fungsi yang Terkandung pada Kitosan+PEG+KCl}

Gugus fungsi C-H (alkana) dengan terdapat pada panjang gelombang $2854 \mathrm{~cm}^{-1}$ sedangkan pada gugus fungsi $-\mathrm{C}=\mathrm{C}$ aromatis terdapat pada bilangan gelombang $1450 \mathrm{~cm}^{-1}$. Gugus fungsi $\mathrm{CH}_{3}$ (tekuk) didapat pada bilangan gelombang $1281 \mathrm{~cm}^{-1}$ dan $1340 \mathrm{~cm}^{-1}$, gugus fungsi C-O didapat pada bilangan 1100, sedangkan gugus fungsi $\mathrm{C}=\mathrm{H}$ (tekuk luar bidang) terdapat pada bilangan $949 \mathrm{~cm}^{-1}$, dan gugus fungsi C-X (alkil halida) terdapat pada bilangan $840 \mathrm{~cm}^{-1}$.

\section{Konduktivitas Polimer Kitosan, PEG, KCl dengan Pengujian LCR}

Konduktivitas ionik merupakan salah satu parameter penting dari suatu elektrolit polimer. Tabel 2 memperlihatkan nilai konduktivitas ionik meningkat dengan semakin meningkatnya konsentrasi $\mathrm{KCl}$ pada rentang $25-45 \%$ yang ditambahkan polimer kitosan dan PEG. Adanya peningkatan konduktivitas ion tersebut disebabkan oleh makin tingginya jumlah ion dan mobilitas dari ion-ion yang terkandung didalam film elektrolit seiring meningkatnya konsentrasi $\mathrm{KCl}$. Konduktivitas ionik pada elektrolit polimer umumnya dipengaruhi oleh jumlah ion yang bergerak dan pergerakan dari ion tersebut. Adapun konduktivitas ionik yang didapat pada kitosan, PEG dan $\mathrm{KCl} 25 \%$ sebesar $12.61547657 \mathrm{~s} / \mathrm{cm}$. sedangkan konduktivitas pada kitosan dengan penambahan $35 \%$ sebesar $180.4409364 \mathrm{~s} / \mathrm{cm}$, sedangkan nilai konduktivitas kitosan $45 \%$ sebesar $326.3195626 \mathrm{~s} / \mathrm{cm}$. penambahan $\mathrm{KCl}$ pada kitosan terbukti meningkat apabila konsentrasinya terus bertambah (Kadafi, 2013).

Penambahan $\mathrm{KCl}$ pada batas tertentu mengakibatkan penurunan nilai konduktivitas ionik elektrolit polimer kitosan/PEG. Konsentrasi ion yang tinggi dalam polimer dapat menghambat pergerakan ion-ion tersebut dan menyebabkan kekakuan pada rantai polimer yang mengakibatkan menurunnya nilai konduktivitas ionik elektrolit polimer. Selain itu, jarak antara ion-ion pada suatu polimer yang terlalu rapat akan menurunkan nilai konduktivitas ionik elektrolit polimer tersebut, sehingga dapat terjadi penggabungan ion dan membentuk pasangan ion netral yang tidak memberikan kontribusi terhadap konduktivitas (Kadafi, 2013).

\section{KESIMPULAN}

Berdasarkan hasil penelitian dari uji konduktivitas film elektrolit polimer kitosan cangkang kepiting dengan penambahan $\mathrm{KCl}$ dapat disimpulkan bahwa:

1. Spektrum FTIR pada kitosan murni menunjukkan adanya gugus fungsi N-H pada bilangan gelombang $344487 \mathrm{~cm}^{-1}$. Gugus fungsi C-O terdeteksi pada bilangan gelombang $1024.20 \mathrm{~cm}^{-1}$. 
2. Gugus fungsi C-H (alkana) dengan terdapat pada panjang gelombang $2854 \mathrm{~cm}^{-1}$ sedangkan pada gugus fungsi $-\mathrm{C}=\mathrm{C}$ aromatis terdapat pada bilangan gelombang 1450 $\mathrm{cm}^{-1}$. Gugus fungsi $\mathrm{CH}_{3}$ (tekuk) didapat pada bilangan gelombang $1281 \mathrm{~cm}^{-1}$ dan 1340 $\mathrm{cm}^{-1}$, gugus fungsi C-O didapat pada bilangan 1100, sedangkan gugus fungsi $\mathrm{C}=\mathrm{H}$ (tekuk luar bidang) terdapat pada bilangan $949 \mathrm{~cm}^{-1}$, dan gugus fungsi C-X (alkil halida) terdapat pada bilangan $840 \mathrm{~cm}^{-1}$.

3. Konduktivitas film elektrolit polimer kitosan meningkat dengan bertambahnya konsentrasi $\mathrm{KCl}$. Adapun pada $25 \%$ konduktivitas yang dihasilkan sebesar $12.61547657 \mathrm{~s} / \mathrm{cm}$. Sedangkan konduktivitas pada kitosan dengan penambahan $35 \%$ sebesar $180.4409364 \mathrm{~s} / \mathrm{cm}$, sedangkan nilai konduktivitas kitosan $45 \%$ sebesar $326.3195626 \mathrm{~s} / \mathrm{cm}$.

\section{SARAN}

Dalam penelitian ini, perlu dilakukan penelitian lebih lanjut mengenai elektrolit polimer yang memiliki nilai konduktivitas lebih tinggi yaitu seperti penambahan bahan polimer dan garam yang lain agar polimer kitosan memiliki tegangan yang lebih besar lagi.

\section{REFERENSI}

Diana, E.P. 2018. Sintesis Membran Elektrolit Padat Berbahan Dasar Kitosan (Synthesis of Chitosan-Based Solid Electrolyte Membrane). Jurnal Sainsmat, Vol VII (2): Halaman 86-91.

Elin, Trisnawati., Dewid Andesti., Abdullah Saleh. 2013. Pembuatan Kitosan dari Limbah Cangkang Kepiting sebagai Bahan Pengawet Buah Duku dengan Variasi Lama Pengawetan. Jurusan Teknik Kimia, Fakultas Teknik, Universitas Sriwijaya. Jl. Raya Palembang Prabumulih Km. 32 Inderalaya Ogan Ilir.

Fonseca, C. Polo and S. Neves. 2006. Electrochemical properties of a biodegradable polymer electrolyte applied to a rechargeable lithium battery. Journal of Power Sources. 159: 712-716.

Kadir, M.F.Z, Z. Aspanal, S.R Majid and A.K. Arof 2011. FTIR studies of plasticized poly (vinyl alcohol)-chitosan blend doped with NH4NO3 polymer electrolyte membrane. Spectrochimica Acta Part A 78 (3): 1068- 1074

Kadapi, M. 2013. Studi Konduktivitas Film Elektrolit Polimer Kitosan+ PEG+KCl. Skripsi IPB. Bogor.

Nurul, A. , Sadillah M. A., Saleh D. 2014. Optimalisasi Sintesis Kitosan dari Cangkang Kepiting sebagai Adsorben Logam Berat Pb (II). Jurnal Fisika dan Aplikasinya, Vol. 15(1).

Osman Z, Ibrahim ZA, Arof AK. 2001. Conductivity enhancement due to ion dissociation in plasticized chitosan based polymer electrolytes. Carbohydrate Polymers 44(2):167173 
Putri Rika., 2009. Studi konduktivitas elektrolit polimer kitosan/PVA+KOH. Fakultas Matematika dan Ilmu Pengetahuan Alam, Institut Pertanian Bogor.

Permana, D. 2015. Synthesis and Characterization of Complex-Composite Membrane Chitosan/Phosphotungstic Acidmontmorillonite Modified by Silane for Direct Methanol Fuel Cell Application. Tesis. Jurusan Kimia Fakultas MIPA, Institut Teknologi sepuluh November. Surabaya.

Shujahadeen, B.A. Abidin, ZHZ. Arof, AK. 2010. Influence of silver ion reduction on electrical modulus parameters of solid polymer electrolyte based on chitosan-silver triflate electrolyte membrane. eXPRESS Polymer Letters 4(5):300-310 .

Yahya, M.Z.A and A.K. Arof. 2003. Effect of oleic acid plasticizer on chitosan-lithium acetate solid polymer electrolytes. Eur Polym. J. 39: 897-902

Yahya MZA, Arof AK. 2004. Conductivity and X-ray photoelectron studies on lithium acetate doped chitosan flms. Carbohydrate Polymers 55(1):95-100.

Yuan, Xiao Zi et al. 2009. Electrochemical Impedance Spectroscopy in PEM fuell Cells. London, Dordrecth, Heidelberg. New York: Springer International Publisher.

SNI, 2006. Standar Nasional Indonesia. Jakarta. 